\title{
FORMATION OF THE TERMINOLOGICAL COMPETENCE OF FUTURE BIOLOGY TEACHERS IN THE INDEPENDENT WORK'S SYSTEM
}

\section{ФОРМУВАННЯ ТЕРМІНОЛОГІЧНОЇ КОМПЕТЕНТНОСТІ МАЙБУТНІХ УЧИТЕЛІВ БІОЛОГІЇ В СИСТЕМІ САМОСТІЙНОї РОБОТИ}

\author{
Victoria PERERVA, \\ Assistant \\ University \\ $\triangle 54$ Gagaryn Avenue, \\ Kryvyi Rih, Ukraine, 50048
}

https://orcid.org/0000-0002-7086-3050

pererva@kdpu.edu.ua

Вікторія ПЕРЕРВА,

асистент

Криворізький державний педагогічний університет просп. Гаааріна, 54, м. Кривий

Ріг, Україна, 50086

Original manuscript received: October 03, 2019

ABSTRACT

Revised manuscript accepted: December 11, 2019

Obtaining high-quality higher education involves the perfect possession of the conceptual field of the chosen specialty, in particular, the terminology of specialty. Among the qualities that need to be formed in the future biology teacher, ones distinguish terminological competence. However, quite often, students and teachers underestimate the importance of this component of professional competence.

The goals of this paper are the identification of the specifics compilation and use of the terminology dictionary as one of the means for shaping the terminological competence of the future teacher and outline the structure of the terminology dictionary from the disciplines of professional orientation on example course "Botany with the basics of geobotany". It is revealed the mastering of professional terms by the future teacher of biology provides the appropriate culture of professional communication. Terminological competence is considered as a component of professional competence and is defined as the ability of a specialist to use special terms in the process of scientific and professional activity. The structure of the terminology dictionary from the discipline "Botany with the basics of geobotany" is outlined; it has a block structure and built on the thematic principle. The system of tasks is given, namely: working out the literature on the specialty, the allocation of the basic and the formulation of the summary pithy characteristic of certain concepts (terms), their fixation, the design a system for the obviousness of terminology (illustration, diagram, chart, intelligence card, infographics, etc.).

It is substantiated the formation of terminological competence of future biology teachers is facilitated by special vocabulary work on the assimilation of the etymology of botanical terms, the discovery of their origin from Latin terms, meaningful comparison and intuitive prediction of the content of lexemes. 
The creation by the future biology teachers the terminology dictionary contributes to improving the quality of their vocational preparation, the shaping of a stable meaningful terminology system, and provides a stable professional motivation.

Keywords: term; terminology dictionary; terminological competence; vocational preparation of the future biology teacher.

Вступ. За сучасних ринкових умов зростають вимоги до профресійної компетентності випускників, що обумовлює введення якісно нових форм та методів їхньої професійної підготовки, спрямованих на створення цілісної системи безперервної освіти, розширення сфери самостійної діяльності, які формують у студентів навички самоорганізації та самоосвіти. Сучасній школі потрібні вчителі-професіонали компетентні, творчі, комунікабельні, із інноваційним педагогічним мисленням, високою професійною культурою, ерудовані, толерантні. Учитель повинен бути як професіоналом, так і високоосвіченою людиною.

Здобуття якісної вищої освіти передбачає досконале володіння поняттєвою сферою обраної спеціальності, зокрема, термінологією свого фаху. Тому з-поміж знань і вмінь, які потрібно сформувати в майбутнього вчителя біології, виокремлюють уміння застосовувати професійну термінологію (Підгурська, 2015). Проте, досить часто студенти та викладачі недооцінюють важливість опанування термінологічного базису наукової картини світу, і це ускладнює фрахову підготовку майбутніх учителів біології.

Розробці проблеми професійної та термінологічної компетентності присвячені праці ряду науковців. Зокрема, питання професійної підготовки майбутніх учителів природничих дисциплін досліджують

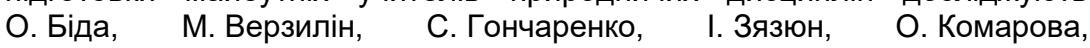
О. Лаврентьєва, І. Мороз, О. Топузов та інші. Сутність та розвиток професійної компетентності сучасного фрахівця розкриті в працях Л. Волошко, Л. Дибкової, І. Зимньої, Д. Іванова, В. Калініна, Г. Копил, Г. Короткової, К. Корсак, А. Маркової, О. Овчарук, А. Онкович, 3. Підручної, А. Хуторського, Т. Шаргун, Л. Шевчук, Н. Уйсімбаєва, С. Шишова та ін. Збагачення мовлення майбутніх фахівців професійноорієнтованою лексикою та методичні засади роботи із засвоєння термінів досліджують Н. Бородіна, В. Борщовецька, О. Копіца, В. Мельничайко, Л. Прокопенко, А. Стебунова та інші.

Проблемі формування професійно-термінологічної компетентності присвячені праці М. Бахтіної, Г. Бондаренко, О. Васічкіної, І. Куламихіної, О. Загородної, К. Кірей, Г. Онуфрієнко, В. Черевко (Власюк, 2013).

Дослідники приділяють значну увагу теоретичним і практичним пошукам, пов'язаним із підготовкою комунікативно компетентного фахівця, що передбачає насамперед володіння професійноорієнтованим мовленням. Проте відсутність визначеної системи роботи 3 формування професійного мовлення майбутніх вчителів біології зумовлює актуальність її окремого вивчення та розробки.

Метою статті $є$ виявлення специфіки складання та використання термінологічного словника як одного із засобів формування 
термінологічної компетентності майбутнього вчителя; окреслення структури термінологічного словника 3 дисциплін професійного спрямування, зокрема "Ботаніки з основами геоботаніки".

Методи та методики дослідження. У статті було використано такі методи дослідження: теоретико-методологічний аналіз, синтез, узагальнення для вивчення літератури 3 проблем дослідження; системно-структурний (класифікація, систематизація); порівняльний (визначення загальних та особливих закономірностей).

Виклад основного матеріалу. Як відомо, засвоєння професійних термінів покликане забезпечити належну культуру фахового спілкування педагога в майбутньому та задоволення його професійних потреб. Правильне оперування фраховою біологічною термінологією - показник ґрунтовності підготовки фахівця. Процес опанування студентами професійно зорієнтованої лексики в закладах вищої освіти доволі складний, що зумовлено постійним зростанням інформаційного потоку, змінами в розподілі годин з навчальних дисциплін, 3 переважанням частки самостійної роботи, порівняно з аудиторною. Несистематичність навчальної діяльності та низький рівень мотивації студентів зумовлює неналежне опанування ними фаховою термінологією, як наслідок неспроможність адекватно сприймати та ґрунтовно засвоювати науковонавчальну інформацію під час опрацювання спеціальної фахової літератури. За таких умов знання можна схарактеризувати як розрізнені, несистематизовані, поверхові і такі, що не здатні забезпечити цілісне уявлення предмета наукового пізнання.

Термінознавство сьогодні переглядає свої традиційні положення щодо сутності терміна, специфріки наукових текстів і розробляє нові проблеми, серед яких чи не найголовнішими $є$ питання фахової мови мови спеціального призначення, структури знань, які стоять за терміном, когнітивні наукові карти, професійну комунікацію тощо (Крохмальна, 2016).

У довідкових джерелах термін - “це спеціальне слово (словосполучення), прийняте в професійній діяльності і таке, що вживається в особливих умовах. Термін - це словесне визначення поняття, яке входить до системи понять певної галузі профресійних знань. Термін - це основний понятійний елемент мови для спеціальних цілей" (Стасюк, 2013). Понятійна природа наукового терміна виявляється в його пізнавальних функціях (Табанакова, 2011).

Критерієм якості підготовки випускника $€$ його профресійна компетентність - інтегративна характеристика ділових і особистих якостей фахівця, що відображає рівень знань, умінь, досвіду, достатніх для досягнення мети з певного виду професійної діяльності, а також його моральну позицію (Денищич, 2012).

Формування термінологічної компетентності $€$ однією із головних складових професійної компетентності, важливим етапом у підготовці майбутнього вчителя-предметника, оскільки володіння термінологічнопонятійним апаратом належить до категорії спеціальних знань (Лаврентьєва, 2011). 
Серія: Педагогічні науки. - Вип.3. - Бердянськ : БДПУ, 2019. - 453 с.

Термінологічна компетентність $є$ здатністю фахівця послуговуватися спеціальними термінами в процесі наукової та професійної діяльності, що визначається наявністю в нього функціональної системи спеціальних знань, когнітивних умінь і практичних навичок та спеціальних здібностей (Гриджук, 2016).

Майбутні вчителі біології мають бути термінологічно компетентними у сфері своєї професійної діяльності. Під термінологічною компетентністю варто розуміти вміння добирати терміни згідно з темою, застосовувати їх відповідно до дефініції, розрізняти терміни та професіоналізми (Стасюк, 2013).

Зі свого боку, термінологічна компетентність формується на основі нерозривного поєднання глибоких знань із фаху зі знанням мовних норм, законів і механізмів фрункціонування як логіко-поняттєвої, так і лексичної підсистем терміносистеми, або, іншими словами, термінологічна компетентність $€$ синтезом фахової ерудиції з термінознавчою (Стасюк, 2013).

3 точки зору генезису виникнення "термінологія" в системі мови може розглядатися як одна з форм професійного соціолекту. На рівні 3 "термінологією" вчені вживають також такі поняття, як "спеціальна підмова”, “професійний соціолект”, “мова спеціальності”, “технолект” і "термінолект", розуміючи останній як узагальнену назву того сукупного мовного явища, яке може бути як “термінологією” у вузькому значенні 3 усіма розвиненими в ній “номенклатурами”, так і таким спеціалізованим для певної галузі науки або техніки мовним утворенням, у якому ще не сорормувалися відмінності між внутрішньо- і зовнішньосутністними характеристиками іменованих одиниць знання (Мельников, 1991).

Соціальним завданням термінолекту $€$ не тільки забезпечення чіткого і місткого позначення предметного світу відповідної професії, а й усунення від справи профанів - недосвідчених людей, які своїми поверховими судженнями завдають шкоди професіоналам, підриваючи престиж професії (Карасик, 1992).

Зазвичай низький рівень володіння фаховим мовленням зумовлює неспроможність студентів адекватно усвідомити, об'єктивно оцінити й ґрунтовно засвоїти знання 3 фахових дисциплін. Урешті-решт формуються несистематизовані, поверхневі й неміцні знання, що унеможливлюють ґрунтовну професійну підготовку, а у майбутньому належний професійний рівень (Крохмальна, 2016).

Розкриємо можливості курсу “Ботаніка з основами геоботаніки" у формуванні термінологічно компетентного майбутнього вчителя біології.

Для спрощеного покрокового опрацювання ботанічної терміносистеми під час вивчення навчальної дисципліни, нами запропоновано зміст тлумачного термінологічного словника, що має блокову структуру. Певний блок відповідає змістовному модулю навчальної дисципліни. У межах блоку терміни наведені в порядку вивчення тем навчальної дисципліни.

Задля формування належного рівня професійного мовлення в майбутніх учителів біології серед питань для самостійного опрацювання 
дисципліни “Ботаніка з основами геоботаніки" розділу “Анатомія та морфологія рослин" розроблено комплекс завдань зі створення словника ботанічних термінів за такими змістовними розділами, як-от: "Будова рослинної клітини", “Тканини рослинних організмів", "Вегетативні органи рослин", “Генеративні органи рослин". Опрацювання та систематизація знань з тем зазначених розділів має на меті формування в студентів усталеного розуміння специфічних біологічних термінів, умінь послуговуватися нами під час вирішення навчальних, а в майбутньому професійних проблем.

Структура тлумачного термінологічного словника відповідає програмі навчальної дисципліни “Ботаніки з основами геоботаніки" і включає такі розділи (блоки):

Модуль І. Анатомія та морфологія рослин". Клітина).

1. Розділ “Будова клітини" (відповідає змістовному модулю І.

Органоїди: одно-, дво- та немембранні; цитоплазма, цитоскелет, симпласт, клітинні включення (кристали: друзи, рафіди, склереїди), крохмальні та алейронові зерна; клітинна стінка та апопласт; клітинний цикл: інтерфаза та поділ клітин (амітоз, мітоз, мейоз).

2. Розділ “Рослинні тканини” (відповідає змістовному модулю II. Тканини):

Твірна тканина: апікальна, латеральна, інтеркалярна, раннєва, первинні та вторинні; покривна тканина: первинна (епідерма, епіблема) та вторинна (перидерма, кора, кірка); основна тканина: аеренхіма, хлоренхіма; провідна тканина: ксилема та флоема; механічна тканина: коленхіма та склеренхіма; видільна тканина: молочники, смоляні ходи, вмістища, гідатоди, нектарники.

3. Розділ "Вегетативні органи рослин" (відповідає змістовному модулю III. Вегетативні органи):

Пагін: галуження моноподіальне, симподіальне, дихотомічне; стебло: типи стебла за розташуванням у просторі, за поперечним перерізом; листок: простий, складний, видозміни; брунька: відкриті та закриті; вегетативні та генеративні; корінь; метаморфози пагону; аналогічні та гомологічні органи.

4. Розділ “Генеративні органи рослин” (відповідає змістовному модулю IV. Відтворення та розмноження рослин):

Квітка: зигоморфна та актиноморфна, одно- та двостатева та ін.; андроцей: одно- дво- та багатобратний, стамінодії та ін.; гінецей: апокарпний, синкарпний, ценокарпний, лізикарпний; насінний зачаток: синергіди, антиподи, халаза, інтегумент та ін.; оцвітина: проста та подвійна; вільно- та зрослопелюсткова та ін.; суцвіття: прості, складні; ботричні, цимозні; моноподіальні та симподіальні; плоди: сухі та соковиті; апокарпні, синкарпні, ценокарпні, лізикарпні.; будова насінини одно- та дводольних рослин, ендосперм; спороношення; статевий процес у рослин; подвійне запліднення квіткових рослин; онтогенез та життєвий цикл рослин. 
Серія: Педагогічні науки. - Вип.3. - Бердянськ : БДПУ, 2019. - 453 с.

Модуль III. Основи геоботаніки.

5. Класифрікація та життєві групи рослин:

Клімаморфи за К.Раункієром; гігроморфи; трофоморфи; геліоморфи; термаморфи; ценоморфи за О.Л. Бельгардом.

Підготовка тематичного словника з певного змістовного модуля навчальної дисципліни передбачає опрацювання літератури за фрахом, виділення основного і формулювання стислої змістовної характеристики певних понять (термінів), що може стати однією з форм індивідуального науково-дослідницького завдання майбутнього вчителя біології.

Зокрема, під час підготовки тлумачного термінологічного словника з "Ботаніки з основами геоботаніки" перед студентами постає завдання 3 опрацювання групи термінів за 5 основними змістовними розділами. Опанування цієї терміносистеми забезпечує ефективне засвоєння навчального матеріалу з ботаніки, про що свідчать показники успішності за результатами модульного контролю. Слід зазначити, що опрацювання термінологічного словника здійснюється кожним студентом самостійно, перевірка засвоєння ботанічних термінів проводиться під час лабораторних занять і консультацій.

Як показали результати, ґрунтовне засвоєння ботанічної терміносистеми забезпечує усунення плутанини в термінах. Наприклад, часто студенти плутаються у формулюваннях таких спецтермінів, як "коленхіма" (механічна тканина) і “ксилема" (провідна тканина); "епідерма", “епіблема", "ризодерма" (покривна тканина); “перицикл" (твірна тканина) та "перидерма" (покривна тканина); “фелоген” (твірна тканина), "фелодерма", "фрелема" (покривна тканина) та "фрлоема" (провідна тканина). Тож, побудована система навчальних завдань і власне створена та апробована структура термінологічного словника закладає основи для майбутнього словника професійної терміносистеми.

3 метою коректного опрацювання та використання спеціальної термінології вважаємо за необхідне розробку системи наочності ілюстрацій, схем, діаграм, інтелект-карт, інфографіки, що здатні доповнити смислове опанування та розуміння спеціальної термінології. Саме тому для студентів із високим рівнем успішності рекомендуємо складати ілюстрований термінологічний словник ботанічних термінів і включати до нього власноруч розроблені чи підібрані ілюстрації. Приділяємо особливу увагу дотриманню студентами академічної доброчесності, виховуємо в них повагу до здобутків учених та дослідників, заохочуємо дискусійні й суперечливі тлумачення окремих термінів.

Слід відмітити, що велику увагу приділяємо осмисленню та засвоєнню етимології ботанічних термінів, виявленню їх походження від латинських термінів. Через спеціальну словникову роботу забезпечуємо осмислене співставлення та навіть можливість інтуїтивного уявлення, передбачення студентами значення поки що незнайомих термінів.

Отже, засвоєння фахової термінології є однією з важливих проблем сучасної педагогічної освіти, яка пов'язана 3 формуванням та вдосконаленням у студентів навчально-пізнавальних умінь і навичок 
оперування науковими термінами, підвищення пізнавальних здібностей студентів під час вивчення природничих фахових та спеціальних дисциплін.

Висновки. Поєднання аудиторної та самостійної роботи 3 опрацювання фахової ботанічної термінології створює умови становлення та вдосконалення професійного мовлення майбутніх вчителів біології, формування в них термінологічної компетентності. Це також забезпечує підвищення якості фахової підготовки вчителяпредметника, формування стійкої осмисленої терміносистеми шляхом створення тлумачного термінологічного словника, який доречно створювати відповідно до змістовних розділів, з подальшим контролем його опанування. Наявність поточного та підсумкового контролю, виділення відповідної кількості балів за створення та опанування термінологічного словника відповідно до кредитно-модульної системи забезпечить стійку мотивацію студентів щодо виконання цієї форми роботи. Одним із перспективних завдань вбачаємо розробку електронного термінологічного словника фахових термінів для підготовки майбутніх учителів біології.

\section{Література}

1. Власюк І. В. Професійно-термінологічна компетентність як складова професійної підготовки майбутніх економістів / І.В. Власюк // Сучасні інформаційні технології та інноваційні методики навчання у підготовиі фрахівців: методологія, теорія, досвід, проблеми. - 2013. - Вип. 35. - С. 204-209.

2. Гриджук О.Є. Компоненти термінологічної компетентності студентів лісотехнічних спеціальностей / О.Є. Гриджук // Педагогіка вищої та середньої школи. - 2016. - Вип. 48. - С. 12-17.

3. Денищич Т. А. Формування термінологічної компетентності майбутніх фахівців з політології / Т.А. Денищич // Наукові праці Чорноморського державного ун-ту. Сер.: Педагогіка. - 2012. - Том 209. - Вип. 197. - С. 137-142

4. Карасик В. И. Язык социального статуса / В.И. Карасик. - М.: Ин-т языкознания РАН. Волгогр. гос. пед. ин-т, 1992. - 330 с.

5. Крохмальна Г. Термінологічна компетентність майбутніх учителів початкової школи: сучасний стан та шляхи вдосконалення / Г. Крохмальна // Вісник Львівського університету. Серія педагогічна. - 2016. - Вип. 30. - С. 110-118

6. Лаврентьєва О. О. Аналіз змісту професійної підготовки майбутнього вчителя природничих дисциплін / О.О. Лаврентьєва // Імідж сучасного педагога. 2011. № 4 113. - С. 23-26.

7. Мельников Г. П. Основы терминоведения / Г.П.Мельников. - М.: Изд-во ун-та дружбы народов. - 1991. - 116 с.

8. Підгурська В. Ю. Формування термінологічного словника у майбутніх учителів початкових класів на україномовних дисциплінах / В.Ю.Підгурська // Актуальні проблеми формування риторичної особистості вчителя в україномовному просторі: збірник наукових праць. - 2015. - С. 89-92..

9. Стасюк Т.В. Нові тенденції розвитку термінознавства: здобутки міжнародної наукової групи Р. Теммерман / Т.В. Стасюк // Термінологічний вісник: Збірник наукових праць. - К. : Інститут української мови НАНУ. - 2013. Вип. 2 (1). $223 \mathrm{c}$.

10. Табанакова В. Д. Идеографическое описание научной терминологии в специальных словарях: дисс. ... д-ра филол. наук / В.Д. Табанакова. - Тюмень: Тюменский гос. ун-т, 2001. - 288 с. 


\section{References}

1.Vlasyuk, I. (2013). Profesiino-terminolohichna kompetentnist yak skladova profesiinoi pidhotovky maibutnikh ekonomistiv [Professional-terminological competence as a component of the vocational preparation of future economists]. Modern information technologies and innovative teaching methods in the training of specialists: methodology, theory, experience, problems. Vol. 35. Pp. 204-209. [in Ukranian].

2.Grydzhuk, O.(2016). Komponenty terminolohichnoi kompetentnosti studentiv lisotekhnichnykh spetsialnostei [Components of terminological competence of students of forest engineering specialties]. Pedagogy of higher and secondary schools. Vol. 48. P. 12-17. [in Ukranian].

3.Denyshchych, T. (2012). Formuvannia terminolohichnoi kompetentnosti maibutnikh fakhivtsiv z politolohii [Formation of terminological competence of future specialists in political science]. Scientific works of the Black Sea State University. Ser: Pedagogy. Vol. 209. 197. P. 137-142. [in Ukranian].

4.Karasyk, V. (1992). Yazyik sotsialnogo statusa [Language of social status]. M.: Institute of Linguistics of the Russian Academy of Sciences. Volgograd state Pedagogical Institute. 330 p. [in Russian].

5.Krohmalna, G. (2016). Terminolohichna kompetentnist maibutnikh uchyteliv pochatkovoi shkoly: suchasnyi stan ta shliakhy vdoskonalennia [Terminological competence of future teachers of elementary school: the current state and ways of improvement]. Visnyk of Lviv University. Pedagogical series. Vol.30. P. 110-118. [in Ukranian].

6.Lavrenteva, O. (2011). Analiz zmistu profesiinoi pidhotovky maibutnoho vchytelia pryrodnychykh dystsyplin [Analysis of the contents of the vocational preparation of the future teacher of natural sciences]. The image of a modern teacher. 2011. № 4 (113). P. 23-26. [in Ukranian].

7.Melnikov, G. (1991). Osnovyi terminovedeniya [Basics of science of terminology]. M.: People's Friendship University. 116 p. [in Russian].

8.Pidgurska, V. (2015). Formuvannia terminolohichnoho slovnyka u maibutnikh uchyteliv pochatkovykh klasiv na ukrainomovnykh dystsyplinakh [Formation of a terminology dictionary for future teachers of elementary school in Ukrainian-language disciplines. Actual problems of forming the rhetorical personality of a teacher in the Ukrainian-speaking space]: collection of scientific works. [in Ukranian].

9.Stasyuk, T. (2013). Novi tendentsii rozvytku terminoznavstva: zdobutky mizhnarodnoi naukovoi hrupy R. Temmerman [New trends in the development of terminology: the achievements of the international scientific group R. Temmerman]. Terminological Visnyk: Collection of scientific works. K.: Institute of the Ukrainian Language of the National Academy of Sciences of Ukraine. Vol. 2 (1). 223 p. [in Ukranian].

10. Tabanakova, V. (2001). Ideograficheskoye opisaniye nauchnoy terminologii v spetsialnykh slovaryakh [Ideographic description of terminology in special dictionaries]: Candidate`s thesis. Tyumen: Tyumen state university. 288 p. [in Russian].

\section{АНОТАЦІЯ}

У статті представлено специфріку складання та використання термінологічного словника як одного із засобів формування термінологічної компетентності майбутнього вчителя в системі самостійної роботи. З'ясовано, що засвоєння профресійних термінів майбутнім учителем біології забезпечує йому належну культуру фахового спілкування та задоволення профресійних потреб, а правильне оперування фраховою біологічною термінологією $є$ показником грунтовності професійної підготовки. Термінологічну компетентність розглянуто як складник профресійної 
компетентності і визначено як здатність фрахівия послуговуватися спеціальними термінами в процесі наукової та профресійної діяльності. Це особистісне утворення визначено як функціональну систему фрахових знань, когнітивних умінь і практичних навичок та спеціальних здібностей фрахівця.

Окреслено структуру термінологічного словника з дисципліни "Ботаніка з основами геоботаніки", що має блокову структуру та побудований за тематичним принципом. Розкрито зміст роботи з формування в майбутніх учителів біології термінологічної компетентності під час складання термінологічного словника. Наведено систему завдань, а саме: опрацювання літератури за фрахом, виділення основного і формулювання стислої змістовної характеристики певних понять (термінів), їх фріксація, розробка системи унаочнення термінології (ілюстрація, схема, діаграма, інтелект-картка, інфоографріка тощо). Обгрунтовано, що фрормуванню термінологічної компетентності майбутніх учителів біології сприяє спеціальна словникова робота із засвоєння етимології ботанічних термінів, виявлення їх походження від латинських термінів, осмисленого співставлення й інтуїтивного передбачення змісту лексем.

Зроблено висновок про те, що створення майбутнім учителем біології термінологічного словника сприяє підвищенню якості його фрахової підготовки, формуванню стійкої осмисленої терміносистеми, забезпечує стійку професійну мотивацію.

Ключові слова: термін; термінологічний словник; термінологічна компетентність; фрахова підготовка майбутнього вчителя біології. 